\title{
PENINGKATAN KINERJA GURU MELALUI SUPERVISI EDUKATIF KOLABORATIF SECARA PERIODIK
}

\author{
Muhammad Noor \\ MIS Misbahussalam Sungai Punggu Lama \\ Anjir Muara Kabupaten Barito Kuala \\ E-mail: m.noorbatola@gmail.com
}

\begin{abstract}
The purpose of this study was to describe the steps of collaborative educative supervision periodically in preparing learning plans, implementing learning, assessing learning achievement, carrying out follow-up on student achievement learning. This research was carried out at MI Missbahussalam Sungai Punggu Lama Subdistrict Anjir Muara there was the 2017/2018 school year. This research is an action research and carried out two cycles with the stages of action preparation, action implementation, monitoring and evaluation, and reflection. Data collection techniques in this study consisted of four main activities, namely the initial data collection, data analysis results at the end of each cycle, and other responses from the teacher on the implementation of collaborative supervision of educational models. The data has been collected and then analyzed by using qualitative and quantitative analysis. Qualitative analysis is used to explain changes in teacher behavior in learning and supervisor behavior in implementing teacher supervision. The results showed that with peer supervision and collaborative educative can improve teacher performance in preparing learning plans, implementing learning, assessing learning achievement and follow-up on the results of assessment of student learning achievement.
\end{abstract}

Keywords: teacher performance; collaborative educational supervision; periodic

\begin{abstract}
ABSTRAK
Tujuan penelitian ini untuk mendeskripsikan langkah-langkah supervisi edukatif kolaboratif secara periodik dalam menyusun rencana pembelajaran, melaksanakan pembelajaran, menilai prestasi belajar, melaksanakan tindak lanjut penialain prestasi belajar siswa. Penelitian ini dilaksanakan di MI Missbahussalam Sungai Punggu Lama Kecamatan Anjir Muara ada tahun pelajaran 2017/2018. Penelitian ini merupakan penelitian tindakan dan dilaksanakan dua siklus dengan tahapan persiapan tindakan, pelaksanaan tindakan, pemantauan dan evaluasi, dan refleksi. Teknik pengumpulan data pada penelitian ini terdiri atas empat kegiatan pokok yakni pengumpulan data awal, data hasil analisis setiap akhir siklus, serta tanggapan lain dari guru terhadap pelaksanaan supervisi edukatif model kolaboratif. Data yang telah dikumpulkan kemudian dianalisis dengan menggunakan analisis kualitatif dan kuantitafif. Analisis kualitatif digunakan untuk menjelaskan perubahan perilaku guru dalam pembelajaran dan perilaku supervisor dalam melaksanakan supervisi guru. Hasil penelitian menunjukkan bahwa dengan adanya supervisi teman sejawat dan edukatif kolaboratif dapat meningkatkan kinerja guru dalam menyusun rencana pembelajaran, melaksanakan pembelajaran, menilai prestasi belajar dan tindak lanjut hasil penilaian prestasi belajar siswa.
\end{abstract}

Kata Kunci: kinerja guru; supervisi edukatif kolaboratif; periodik

\section{PENDAHULUAN}

Untuk meningkatkan mutu pendidikan di Indonesia, pemerintah telah menetapkan Undang-Undang Sistem Pendidikan. Undang-Undang tersebut memuat dua puluh dua bab, tujuh puluh tujuh pasal, dan penjelasannya. Undang-Undang Sistem Pendidikan (2003:38) menjelaskan bahwa setiap pembaruan sistem pendidikan nasional untuk memperbarui visi, 
misi, dan strategi pembangunan pendidikan nasional. Visi pendidikan nasional di antaranya adalah (1) mengupayakan perluasan dan pemerataan kesempatan memperoleh pendidikan yang bermutu bagi seluruh rakyat Indonesia, (2) membantu dan memfasilitasi pengembangan potensi anak bangsa secara utuh sejak usia dini sampai akhir hayat dalam rangka mewujudkan masyarakat belajar, (3) meningkatkan kesiapan masukan dan kualitas proses pendidikn untuk mengoptimalkan pembentukkan keperibadian yang bermoral, (4) meningkatkan keprofesionalan dan akuntabilitas lembaga pendidikan sebagai pusat pembudayaan ilmu pengetahuan, keterampilan, pengalaman, sikap dan nilai berdasarkan standar nasional dan global, (5) memberdayakan peran serta masyarakat dalam penyelengaraan pendidikan berdasarkan prinsip otonomi dalam konteks Negara Kesatuan RI.

Jika mencermati visi pendidikan tersebut, semuanya mengarah pada mutu pendidikan yang akhirnya dapat meningkatkan hasil belajar peserta didik. Mutu pendidikan ternyata dipengaruhi oleh banyak komponen. Menurut Syamsuddin (2005:66), ada tiga komponen utama yang saling berkaitan dan memiliki kedudukan strategis dalam kegiatan belajar mengajar. Ketiga komponen tersebut adalah kurikulum, guu dan pembelajar (siswa). Ketiga komponen itu, gurulah yang menduduki posisi sentral sebab peranannya sangat menentukkan. Dalam pembelajaran, seorang guru harus mampu menerjemahkan nilai-nilai yang terdapat dalam kurikulum secara optimal. Walaupun sistem pembelajaran sekarang sudah tidak theacher center lagi, seorang guru harus tetap memegang peranan yang penting dalam membimbing siswa. Bahkan menurut Undang-Undang Guru pasal 1 ayat 1 (2006;3) guru adalah pendidik profesioanal dengan tugas utama, yaitu mendidik, mengajar, membimbing, mengarahkan, melatih, menilai, dan mengevaluasi peserta didik pada pendidikan anak usia dini jalur pendidikan formal, pendidikan dasar, dan pendidikan menengah. Berdasarkan hal itu, seorang guru harus mempunyai pengetahuan yang memadai baik di bidang akademik maupun pedagogik. Menurut Djazuli (1996:2), seorang guru dituntut memiliki wawasan yang berhubungan kependidikan untuk menyampaikan isi pengajaran kepada siswa. Kedua wawasan tersebut merupakan satu-kesatuan yang tidak dapat dipisahkan.

Seorang guru harus selalu meningkatkan kemampan profesionalnya, pengetahuan, sikap, dan keterampilannya secara terus-menerus sesuai perkembangan ilmu pengetahuan dan teknologi, termasuk paradigma baru pendidikan yang menerapkan Manajemin Berbasis Sekolah (MBS) dan Kuriulum Berbasis Kompetensi (KBK). Menurut Ditjen Pendidikan Dasar dan Meenengah, Dapertemen Pendidikan Nasional (2004: 2), seoranng guru harus memenuhi tiga standar kompetensi, di antaranya: (1) Kompetensi Pengeloaan Pembelajaran dan Wawasan Kependidikan, (2) Kompetensi Akademik/ Vokasional sesuai materi pembelajaran, (3) Pengembangan Profesi. Ketiga kompetensi tersebut bertujuan agar bermutu menjadikan pembelajaran bermutu juga, yang akhirnya meningkatkan mutu pendidikan Indonesia.

Untuk mncapai tiga kompetensi tersebut, sekolah harus melaksanakan pembinaan terhadap guru baik melalui workshop, PKG, diskusi, dan supervise edukatif. Hal itu harus dilakukan secara periodik agar kinerja dan wawasan guru bertambah. Sebab, berdasarkan diskusi yang dilakukan guru di MI Missbahulsalam Sungai Punggu Lama, rendahnya kinerja dan wawasan guru diakibatkan oleh: (1) Rendahnya kesadaran guru untuk belajar, (2) kurangya kesempatan guru mengikuti pelatihan, baik secara regional maupun nasional, (3) kurang efektifnya PKG, (4) supervisi pendidikan yang bertujuan memperbaiki proses pembelajaran cenderung menitikberatkan pada aspek administrasi.

Untuk memperbaiki kinerja dan wawasan guru dalam pembelajaran di MI Missbahulsalam Sungai Punggu Lama, sekolah melaksanakan penelitian tindakan yang berkaitan dengan permasalahan di atas. Karena keterbatasan peneliti, penelitian ini hanya difokuskan pada supervise edukatif saja, sehingga judul penelitian tindakan tersebut adalah "Peningkatan Kinerja Guru Melalui Supervisi Edukatif Kolabratif secara Periodik'. Tujuan 
penelitian ini untuk mendeskripsikan langkah-langkah supervisi edukatif kolaboratif secara periodic dalam menyusun rencana pembelajaran, melaksanakan pembelajaran, menilai prestasi belajar, melaksanakan tindak lanjut penialain prestasi belajar siswa.

Karena supervisi edukatif melibatkan supervisor, guru, siswa, dan lingkungan, dalam penelitian tindakan ini, peneliti sebagai kepala madrasah dan sekaligus calon pengawas bersama semua guru MI Missbahulsalam Sungai Punggu Lama, mengidentifikasi masalah pembelajaran. Selanjutnya, menentukan langkah-langkah pemecahan, yakni: (1) mengadakan workshop singkat tentang pembuatan persiapan pembelajaran, pelaksanaan, dan penilaian pembelajaran di sekolah, (2) melaksanakan supervisi edukatif kolaboratif secara periodik dengan menekankan pada pemberian bantuan untuk perbaikan pembelajaran.

\section{METODE PENELITIAN}

Penelitian ini dilaksanakan di MI Missbahussalam Sungai Punggu Lama Kecamatan Anjir Muara ada tahun pelajaran 2017/2018. Peneliti mengambil tempat penelitian di MI Missbahussalam Sungai Punggu Lama Kecamatan Anjir Muara karena ditempat itu peneliti bekerja dan di dalamnya beragam guru. Ada yang dari GTT, GB, PNS, dan ijazahnya pun beragam, yakni; ada yang berijazah diploma, sarjana, dan pascaserjana. Waktu penelitian ini adalah pada tahun pelajaran 2017/2018. Selama penelitian tersebut peneliti mengumpulkan data awal, menyusun program supervisi, pelaksanaan supervisi, analisis, dan tindak lanjut.

Ada beberapa faktor yang diselidiki, yaitu sebagai berikut:

1. Guru, melihat peningkatan kemampuan guru dalam membuat rencana pembelajaran, melaksanakan tindak lanjut hasil penilaian prestasi belajar siswa sebelum penelitian dan dalam penelitian tindakan.

2. Pembelajaran, memperhatikan keefektifan pembelajaran dikelas yang dikelola oleh guru dengan menerapkan strategi pembelajaran yang sesuai dengan materi pembelajaran.

3. Siswa, memperhatikan motivasi belajar siswa, hasil belajar yang dilihat, dan hasil nilai ujian akhir nasional, khusus mata pelajaran bahasa Indonesia; IPA; matematika.

4. Supervisor, memperhatikan tindakan supervisor selama melakukan supervisi edukatif.

Karena penelitian ini merupakan penelitian tindakan, pelaksanaan ini dilaksanakan secara siklus. Pelaksanaannya selama dua siklus. Siklus-siklus itu merupakan rangkaian yang saling berkelanjutan. Maksudnya, siklus ke dua merupakan kelanjutan dari siklus pertama. Setiap siklusnya selalu ada persiapan tindakan, pelaksanaan tindakan, pemantauan dan evaluasi, dan refleksi. Langkah-langkah penelitian tindakan itu sebagai berikut.

\section{Langkah-Langkah Pelaksanaan Siklus I \\ a. Persiapan Tindakan}

Siklus pertama dilaksanakan selama satu semester, yaitu semester ganjil tahun 2017/2018 dengan kegiatan sebagai berikut.

1. Pengumpulan data awal diambil dari daftar keadaan guru untuk mengetahui pendidikan terakhir, pelatihan yang pernah diikuti guru, dan lamanya guru bertugas. Data awal kerja guru dan efektivitas pembelajaran dilihatdari hasil supervisi kunjungan kelas masingmasing guru sebelum dilaksanakan penelitian.

2. Mengadakan pertemuan guru-guru sebgai mitra penelitian membahas langkah-langkah pemecahan masalah pembelajaran dari aspek guru dan supervisor.

3. Merumuskan langkah-langkah tindakan yang akan dilaksanakan pada siklus pertama.

\section{b. Pelaksanaan Tindakan}

Pelaksanaan tindakan ini dilakukan oleh peneliti dan supervisor selama kegiatan belajar mengajar berlangsung dengan tindakan sebagai berikut.

1. Mengadakan penelitian guru selama membuat program pembelajaran melalui workshop sekolah. 
2. Melaksanakan supervisi edukatif selama pembelajaran secara periodik dengan system kolaboratif.

3. Pemberian reward dari kegiatan-kegiatan dalam bentuk penilaian angka kredit jabatan fungsional guru sebagai syarat kenaikan pangkat.

\section{c. Pemantauan dan Evaluasi}

Pada prinsipnya, pemantauan diaksanakan selama penelitian berlangsung dengan sasaran utama untuk melihat peningkatan kemampuan guru serta efektifitas pembelajaran yang dilaksanakan oleh guru serta tindakan-tindakan supervisor dalam mensupervisi guru tersebut. Adapun instrumen yang digunakan untuk memantau tindakan guru dalam pembelajaran dan supervisor dalam mensupervisi berupa:

1. Professional, guru yang memiliki komitmen tinggi dan kemampuan berpikir tinggi;

2. Analitis, guru yang memiliki kemampuan berpikir tinggi tetapi komitmennya rendah;

3. Tidak terfokus atau bingung guru yang memiliki kometmen tinggi, tetapi kemampuan berpikirnya rendah;

4. Gagal, guru memiliki komitmen rendah dan kemampuan berpikirnya juga rendah;

5. Tindakan supervisor sebelum pelaksanaan supervisi;

6. Tindakan supervisor selama pelaksanaan supervisi;

7. Tindakan supervisor setelah pelaksanaan supervisi;

8. Aktivitas guru dalam melaksanakan pembelajaran di kelas.

\section{d. Refleksi}

Refleksi mrupakan kegiatan yang meliputi analisis, sinetetis, memaknai, menerangkan, dan akhirnya menyimpulkan semua informasi yang diperoleh pada saat persiapan dan tindakan. Hasil refleki dimanfaatkan untuk perbaikan pada siklus berikutnya. Guru, peneliti, dan supervisor pada tahap ini mendiskusikan pelaksanaan proses tindakan yang dilakukan berdasarkan hasil pengamatan selama guru menyusun rencana pembelajaran, melaksanakan pembelajaran, menilai prestasi belajar, melaksanakan tindak lanjut hasil penilaian prestasi belajar siswa dan supervisi melakukan tindakan. Hal yang didiskusikan meliputi (a) kesesuaian pembelajaran dengan perencanaan, (b) materi yang digunakan pembelajaran, (c) evaluasi pembelajaran, (d) kesesuaian tindakan guru dengan format supervisi, (e) tindak lanjut supervisor dan guru.

\section{Gambaran Siklus II}

Siklus II dilaksanakan selama satu semester, yakni semester genap tahun pelajaran 2017/2018 dan merupakan kelanjutan serta perbaikan siklus I. kegiatan siklus kedua didasarkan pada hasil siklus pertama dengan rangkaian (a) persiapan tindakan, (b) Pelaksanaan Tindakan, (c) pemantauan dan evaluasi, (d) refleksi.

Teknik pengumpulan data pada penelitian ini terdiri atas empat kegiata pokok yakni pengumpulan data awal, data hasil analisis setiap akhir siklus, serta tanggapan lain dari guru terhadap pelaksanaan supervisi edukatif model kolaboratif. Data yang telah dikumpulkan kemudian dianalisis dengan menggunakan analisis kualitatif dan kuantitafif. Analisis kualitatif digunakan untuk menjelaskan perubahan perilaku guru dalam pembelajaran dan perilaku supervisor dalam melaksanakan supervisi guru. Adapun analisis kuantitatif digunakan untuk mengetahui keberhasilan guru dan siswa berdasarkan standar kompetensi guru yang telah ditetapkan oleh Depdiknas sebagai berikut.
a. Nilai 91-100 = amat baik (A) berhasil
b. Nilai 76-90 = baik (B) berhasil
c. Nilai 55-75 = cukup (C) belum berhasil
d. Nilai 0-54= kurang (D) belum berhasil

Keseluruhan data yang terkumpul, seanjutnya dipergunakan untuk menilai keberhasilan tindakan yang diberikan dengan indicator keberhasilan sebagai berikut.

1. Terjadi peningkatan kinerja guru dalam menyusun rencana pembelajaran 
2. Terjadinya peningkatan kinerja guru dalam melaksanakan pembelajaran.

3. Terjadinya peningkatan kinerja guru dalam menilai prestasi belajar siswa

4. Terjadinya peningkatan kinerja guru dalam melaksanakan tindak lanjut hasil penilaian prestasi belajar siswa

5. Terjadinya pembelajaran efektif yang mampu memotivasi belajar siswa dengan meningkatnya hasil belajar, terutama nilai Ujian Akhir Sekolah (nilai UAS).

\section{HASIL PENELITIAN DAN PEMBAHASAN}

\section{A. Hasil Siklus I}

Berdasarkan pemantauan selama persiapan, pelaksanaan, dan tindak lanjut penelitian tindakan ini diperoleh berbagai data, baik dari guru yang sedang melaksanakan proses belajar mengajar siswa yang belajar maupun supervisor yang sedang melaksanakan supervisinya. Gambaran yang merupakan hasill dan temuan penelitian adalah sebagai berikut.

\section{Perencanaan Supervisi Siklus I}

Supervisor bersama guru membuat perencanaan yang berkaitan dengan pembuatan instrument penelitian. Instrumen tersebut dibuat beerdasarkan indikator yang dibuat oleh Dapertemen Pendidikan Nasional. Hasil perencanaan supervise siklus I ditunjukkan pada Tabel 1.

Tabel 1 Hasil Penentuan Perencanaan Siklus I

\begin{tabular}{|c|c|c|c|c|}
\hline No & Indikator & $\begin{array}{c}\text { Jumlah } \\
\text { Guru }\end{array}$ & $\begin{array}{c}\text { Jumlah Guru } \\
\text { Berhasil (Skor }>75)\end{array}$ & $\begin{array}{c}\% \\
\text { Keberhasilan } \\
\end{array}$ \\
\hline 1. & Mendeskripsikan Tujuan Pembelajaran & 10 & 9 & 90 \\
\hline 2. & $\begin{array}{l}\text { Menentukan materi sesuai dengan } \\
\text { kompetensi }\end{array}$ & 10 & 9 & 90 \\
\hline 3. & $\begin{array}{l}\text { Mengorganisasikan materi berdasarkan } \\
\text { urutan atau kelompok }\end{array}$ & 10 & 7 & 70 \\
\hline 4. & Mengalokasikan waktu & 10 & 10 & 100 \\
\hline 5. & Menentukan metode pembelajaran & 10 & 6 & 60 \\
\hline 6. & Merancang prosedur pembelajaran & 10 & 7 & 70 \\
\hline 7. & Menentukan media pembelajaran & 10 & 7 & 70 \\
\hline 8. & $\begin{array}{l}\text { Menentukkan sumber belajar yang sesuai } \\
\text { (berupa buku, modul program computer, dan } \\
\text { sejenisnya) }\end{array}$ & 10 & 9 & 90 \\
\hline 9. & Menentukan teknik penilaian yang sesuai & 10 & 4 & 40 \\
\hline & Jumlah Keberhasilan & 10 & 68 & 76 \\
\hline
\end{tabular}

Berdasarkan instrumen tersebut, guru akhirnya membuat perencanaan pembelajaran yang alurnya sama dengan instrumen supervisi tersebut. Berdasarkan data yang dikumpulkan, ternyata hampir semua guru dapat membuat perencanaan tersebut, tetapi hasilnya jika kita ukur dengan indikator yang telah ditetapkan, masih ada yang kurang.

\section{Pelaksanaan Supervisi Siklus I}

Instrumen penelitian yang digunakan berupa instrumen yang sesuai dengan indikator yang di buat oleh Depdiknas dan hasil pelaksanaan supervise siklus I ada pada Tabel 2.

Tabel 2. Hasil Pelaksanaan Pembelajaran Tindakan Siklus I

\begin{tabular}{|l|l|c|c|c|}
\hline No & \multicolumn{1}{|c|}{ Indikator } & $\begin{array}{c}\text { Jumlah } \\
\text { Guru }\end{array}$ & $\begin{array}{c}\text { Jumlah Guru } \\
\text { Berhasil (Skor> 75) }\end{array}$ & $\begin{array}{c}\text { \% } \\
\text { Keberhasilan }\end{array}$ \\
\hline 1. & $\begin{array}{l}\text { Membuka pelajaran dengan metode yang } \\
\text { tepat. }\end{array}$ & 10 & 8 & 80 \\
2. & $\begin{array}{l}\text { Menyajikan materi pembelajaran secara } \\
\text { sistematis }\end{array}$ & 10 & 6 & 60 \\
\hline
\end{tabular}




\begin{tabular}{|l|l|c|c|c|}
\hline 3. & Menerapkan metode dan prosedur & 10 & 6 & 60 \\
4. & pembelajaran yang telah ditentukan & 10 & 9 & 90 \\
5. & Mengatur kegiatan siswa dikelas & 10 & 5 & 50 \\
6. & Menggunakan media pembelajaran & 10 & 10 & 100 \\
7. & Memotivasi siswa dengan berbagai cara & 10 & 9 & 90 \\
8ang positif interaksi dengn siswa & 10 & 9 & 90 \\
8. & Melakukan belajar & 5 & 50 \\
9. & Menggunakan bahasa yang komonikatif. & 10 & 6 & 60 \\
10. & Menympulkan pembelajaran bantik & 10 & 5 & 50 \\
11. & Menggunakan waktu secara efektif & 10 & 78 & 71 \\
\hline & Jumlah Keberhasilan & & \\
\hline
\end{tabular}

\section{Penilaian Supervisi Siklus I}

Instrumen penilaian yang digunakan dalam penelitian tindakan berupa instrumen yang sesuai dengan indikator yang dibuat oleh Depdiknas dan hasil penilaian supervisi ditunjukkan pada Tabel 3.

Tabel 3 Hasil Menilai Prestasi Belajar Siklus I

\begin{tabular}{|l|l|c|c|c|}
\hline No & \multicolumn{1}{|c|}{ Indikator } & $\begin{array}{c}\text { Jumlah } \\
\text { Guru }\end{array}$ & $\begin{array}{c}\text { Jumlah Guru } \\
\text { Berhasil (Skor> 75) }\end{array}$ & $\begin{array}{c}\text { \% } \\
\text { Keberhasilan }\end{array}$ \\
\hline 1. & Menyusun soal/perangkat penilaian & 10 & 9 & 90 \\
2. & Melaksanakan penilaian & 10 & 9 & 90 \\
3. & Memeriksa jawaban/member skor & 10 & 7 & 70 \\
4. & Menilai hasil belajar & 10 & 10 & 100 \\
5. & Mengolah hasil belajar & 10 & 6 & 60 \\
6. & Menganalisis hasil belajar & 10 & 7 & 70 \\
7. & Menyimpulkan hasil belajar & 10 & 7 & 100 \\
8 & Menyusun laporan hasil belajar & 10 & 10 & 100 \\
9. & Memperbaiki soal/perngkat penilaian & 10 & 10 & 73 \\
\hline & Jumlah Keberhasilan & & 75 & \\
\hline
\end{tabular}

\section{Pelaksanaan Tindak Lanjut Hasil Penilaian Siklus I}

Kegiatan ini dilaksanakan oleh guru pada bagian terakhir setelah melaksanakan penilaian dengan tujuan menganalisis program penilaian dan perbaikan hasil penilaian. Adapun instrumen yang digunakan untuk menjaring data berupa indikator yang dibuat oleh Depdiknas $(2004 ; 12)$ dan hasil pelaksanaan tindak lanjut ditunjukkan pada Tabel 4.

Tabel 4 Hasil Melaksanakan Tindak Lanjut Hasil Penilaian Siklus I

\begin{tabular}{|c|c|c|c|c|}
\hline No & Indikator & $\begin{array}{c}\text { Jumlah } \\
\text { Guru }\end{array}$ & $\begin{array}{c}\text { Jumlah Guru } \\
\text { Berhasil (Skor }>75)\end{array}$ & $\begin{array}{c}\% \\
\text { Keberhasilan } \\
\end{array}$ \\
\hline 1. & $\begin{array}{l}\text { Mengidentifikasi kebutuhan tindak lanjut } \\
\text { hasil penilaian }\end{array}$ & 10 & 6 & 60 \\
\hline 2. & Menyusun program tindak lanjut & 10 & 7 & 70 \\
\hline 3. & Melaksanakan tindak lanjut & 10 & 5 & 50 \\
\hline 4. & $\begin{array}{l}\text { Mengevaluasi hasil tindak lanjut penilaian } \\
\text { Menganalisis hasil evaluasi program tindak }\end{array}$ & 10 & 5 & 50 \\
\hline 5. & Lanjut hasil penilaian & 10 & 4 & 40 \\
\hline & Rata-rata keberhasilan & 10 & 27 & 54 \\
\hline
\end{tabular}




\section{Tindakan Supervisor Siklus I}

Tindakan supervisor pada pelaksanaan supervisi siklus pertama sebagai berikut. (1) supervisi memberikan indikator yang harus dicapai pada saat persiapan, pelaksanaan, dan penilaian seminggu sebelum pelaksanaan supervise, (2) supervisor menyuruh guru mengisi format penilaian serta membuat perencanaan kembali kegiatan berikut yang akan disupervisi.

\section{Refleksi Siklus I}

\section{a. Refleksi Perencanaan Supervisi Siklus I}

Setelah dilaksanakan diskusi dengan guru mata pelajaran dan supervisor, peneliti menulis hasil refleksi sebagai berikut.

1. Mendeskripsikan tujuan pembelajaran 28 guru dengan persentase $90 \%$. Berdasarkan data tersebut kegiatan guru sudah sangat baik. Kegiatan seperti itu dipertahankan tetapi ada beberapa guru yang perlu dimotivasi.

2. Menentukan materi sesuai dengan kompetensi yang telah ditentukan sebanyak 30 guru dengan persentase $97 \%$.

3. Mengorganisasikan materi berdasarkan urutan dan kelompok sebanyak 21 guru dengan persentase $68 \%$. Pada bagian ini guru perlu diberi bimbingan lagi tentang bagaimana mengorganisasikan materi berdasarkan urutannya. Guru diberi contoh pembelajaran berdasarkan pembelajaran CTL dan CL.

4. Mengalokasikan waktu sebanyak 31 guru dengan persentase $100 \%$. Kegiatan pada bagian ini dipertahankan yakni menentukan alokasi waktu melalui workshop guru mata pelajaran di sekolah dengan dipandu guru senior.

5. Menentukan metode pembelajaran yang sesuai, sebanyak 18 guru dengan persentase 59\%. Berdasarkan catatan dan hasil pelaksanaan ternyata pada bagian ini guru perlu diberi bimbingan dan pengarahan secara berdiskusi dengan supervisor dan guru senior untuk menetapkan metode yang berkaitan dengan kontekstual.

6. Merancang prosedur pembelajaran sebanyak 7 guru dengan persentase $70 \%$. Pada penentuan prosedur sangat berkaitan denngan metode pembelajaran. Oleh sebab itu, perlu ada perbaikan di bidang ini.

7. Menentukan media pembelajaran/ peralatan praktikum (dan bahan) yang akan digunakan sebanyak 7 guru dengan persentase $70 \%$. Guru pada bagian ini masih terfokus pada media yang dibeli atau dibuat oleh perusahaan padahal disekitar kelas banyak media alami yang bisa digunakan sebagai media. Bagian ini, masih perlu diperbaiki.

8. Menentukan sumber belajar yang sesuai (berupa buku, modul, program computer, dan sejenisnya) sebanyak 9 guru dengan persentase $90 \%$.

9. Menentukan teknik penilaian sebanyak 4 guru dengan prsentase $40 \%$. Teknik-teknik yang dibuat guru dalam menyusun penelitian masih kurang beragam.

\section{b. Reflesi Pelaksanaan Supervisi Siklus I}

Hasil refleksi pada bagian pelaksanaan supervisi dan setelah diadakan diskusi guru, peneliti, dan supervisor sebagai berikut.

1. Membuka pelajaran dengan metode yang sesuai. Guru rata-rata sudah mampu membuka pelajaran dengan tepat sebanyak 8 orang atau dengan persentase $80 \%$. Berdasarkan persentase diatas, guru perlu mempertahankan cara tersebut.

2. Menyajikan materi pelajaran. Dalam menyajikan materi pelajaran, guru rata-rata sudah baik dan berdasarkan penamatan ada guru yang dikategorikan baik. Jika hal itu dipersentasekan, sudah mencapai $60 \%$.

3. Menerapkan metode dan prosedur pembelajaran yang telah ditentukan berjumlah 6 guru dengan persentase $60 \%$. Guru dalam menggunakan metode masih terfokus pada metode tradisional. Sebagai perbaikan, guru yang masih belum paham dalam menggunakan metode pembelajaran modern diwajibkan membaca buku-buku yang berkaitan metode pembelajaran modern, terutama buku CTL dan diberi contoh pembelajaran modern. 
4. Mengatur egiatan siswa dikelas berjumlah 9 guru dengan persentase $90 \%$. Berdasarkan data tersebut, guru sudah banyak yang mampu mengelola kelas. Guru yang belum berhasil mengelola kelas dengan baik diajak diskusi pada pasca supervisi.

5. Menggunakan media pembelajaran/ peralatan praktikum (dan bahan) yang telah ditentukan berjumlah 5 guru dengan persentase 50\%. Guru masih jarang menggunakan alat-alat yang bisa menguatkan pemelajaran. Hal itu dikarenakan belum paham pembelajaran CTL.

6. Menggunakan sumber belajar yang telah dipilih (berupa buku modul program computer, dan sejenisnya) berjumlah 10 guru dengan persentase $100 \%$. Pada bagian ini guru sudah tidak masalah lagi. Namun, kepala sekolah, supervisor harus terus memotivasi guru-guru tersebut.

7. Memotivasi siswa dengan berbagai cara yang positif, berjumlah 27 guru dengan persentase $90 \%$. Guru sudah banyak yang memotivasi siswa yang jarang member motivasi pada siswa rata-rata guru senior. Hal ini terjadi karena masih terpengaruh pada pendidikan lama. Guru seperti itu perlu diajak diskusi tentang keunggulan member motivasi kepada siswa.

8. Melakukan interaksi dengan siswa menggunakan bahasa yang komunikatif berjumllah 9 guru dengan persentase $90 \%$. Ada tiga guru yang masih menggunakan bahasa yang sulit dipahami siswa. Hal itu terjadi pada guru junior.

9. Memberikan pertanyaan dan umpan balik. Halini dilakukan untk mengetahui dan memerlukan penerimaan siswa dalam proses belajar bberjumlah 5 guru dengan persentase $50 \%$. Guru masih jarang memberikan umpan balik pada siswa. Rata-rata hanya mengerjakan soal-oal di KS sampai waktunya habis. Untuk mengatasi hal tersebut, guru disuruh merencanakan penyajian materi dengan memperhatikan waktu yang digunakan.

10. Menyimpulkan pembelajaran berjumlah 6 guru dengan persentase $60 \%$. Guru masih banyak yang belum menyimpulkan pembelajaran. Jhal ini terjadi karena waktunya habis digunakan mengerjakan LKS saja. Untuk itu perlu disesuaikan soal-soal yang dikerjakan dalam LKS itu.

11. Menggunakan waktu ecara efektifdan efisien berjumlah 5 guru dengan persentase $50 \%$. Guru kurang efektif dalam menggunakan waktu pembelajaran jika dikaitkan dengan langkah-langkah yang ada dalam indicator tersebut karena waktunya hanya tersita pada mengerjakan LKS saja. Untuk itu, perlu direncanakan dengan baik.

\section{c. Refleksi Penilaian Supervisi Siklus I}

Hasil refleksi pada bagian penilaian supervisi dan setelah diadakan diskusi dengan guru, penelitian, dan supervisor adalah sebagai berikut.

1. Menyusun soal/perangkat penilaian sesuai untuk indikator/kriteria untuk kerja yang telah ditentukan berjumlah 9 guru dengan persentase $90 \%$. Masih ada beberapa guru yang belum mampu menyusun soal penilaian karena masih tidak sesuai dengan indikatornya. Berdasarkan pengamatan/analisis, ternyata guru tersebut belum paham betul pada kerja yang ada dalam indikator tersebut. Oleh sebab itu, guru-guru itu masih perlu belajar bersama tentang indicator tersebut.

2. Melaksanakan penilaian berjumlah 9 guru dengan persentase $90 \%$. Masih ada guru yang membiarkan siswanya membuka-buka buku dalam ulangan tersebut. Hal seperti ini akan merugikan anak. Bahkan, penilaian itu tidak bisa digunakan untuk mengukur kemampuan siswa. Guru seperti ini perlu diberi bimbingan secara khusus tentang pentingnya penilaian.

3. Memeriksa jawaban/memberikan skor tes hasil belajar berdasarkan indikator/kriteria unjuk kerja yang telah ditentukan berjumlah 7 guru dengan persentase $70 \%$. Guru yang belum mampu memberikan skor, rata-rata guru junior yang belum pernah mengikuti 
pelatihan. Skor dianggap sama dengan bobot. Untuk mengatasi seperti itu, guru-guuru tersebut diikutkan MGMP kabupaten atau diberi bimbingan secara khusus.

4. Menilai hasil belajar siswa berjumlah 10 guru dengan persentase $100 \%$. Semua guru sudah mampu indikator ini.

5. Mengolah hasil penilaian berjumlah 18 guru dengan persentase $60 \%$. Guru yang belum mampu mengolah nilai sebagian besar sama dengan guru yan g tidak paham terhadap penyekoran pembobotan nilai.

6. Menganalisis hasil penilaian (berdasarkan tingkat kesukaran, daya pembeda, validitas, dan reabilitas) berjumlah 7 guru dengan persentase $70 \%$. Guru yang tidak bisa menganalisis soal rata-rata guru yang enggan menganalisis atau tidak mau menganalisis sehingga lupa cara menganalisis . untuk men ghadapi seperti itu, sekolah perlu mengadakan workshop di sekolah.

7. Menyimpulkan hasil penilaian secara jelas dan logis (misaln ya; interpretasi kecen derungan hasil penilaian, tingkat pencapaian siswa, dll) berjumlah 7 guru dengan persentase $70 \%$. Karena tidak bisa menganalisis butir soal, guru tersebut tidak bisa menyimpulkan penilaian secara logis dan jelas. Untuk mengatasi hal itu, guru terse but diajak diskusi tau diajak disuruh mengikuti workshop di sekolah.

8. Menyusun lapotran hasil penilaian berjumlah 10 guru dengan ersentase $100 \%$. Guru yang tidak $\mathrm{b}$ isa melaporkan hasil penilaian rata-rtata, guru terse but malasmembuat laporan. Karena seperti itu, kepala sekolah harus memotivasi terhadap gfuru bahwa betapa pentingnya memmbuat laporan penilain.

9. Memperbaiki oal/perangfkat penilaian bertjumlah 10 gfuru dengfan persentase $100 \%$. Guru yang tidak mampu memperbaiki soal yang jelek sebagian besar guru yang kurang paham tehadap indicator dalam kisi-kisi penilaian. Untuk mengatasi itu, guru tersebut diajak diskusi atau kerja kelompok.

\section{d. Refleksi Pelaksanaan Tindak Lanjut Penilaian Siklus I}

Refleksi pada bagian tindak lanjut ini diilakukan berdasarkan pada data yang dikumpulkan oleh supervisor dan dianalisis lalu dicarikan solusinya. Hasil refleksinya adalah sebagai berikut.

1. Mengidentifikasi kebutuhan tindak lanjut hasil penilaian berjumlah 6 guru dengan persentase $60 \%$. Pada bagian ini masih banyak guru yang belum mampu mengidentifikasi kebutuhan indak lanjut. Oleh sebab itu, pada siklus berikutnya guru tersebut diajak berdiskusi betapa pentingnya pelaksanaan tndak lanjut tersebut.

2. Menyusun program tindak lanjut hasil penilaian berjumlah 7 guru, dengan persentase $70 \%$. Guru yang belum mampu menyusun program tindak lanjut perlu melaksanakan workshop sekolah atau dengan dibimbing oleh supervisor/ guru senior guru tersebut untuk menyusun program tindak lanjut.

3. Mellaksanakan tindak lanjut berjumlah 5 guru, dengan persentase $50 \%$. Karena guru banyak yang belum menyusun program, pelaksanaannya pun masih sedikit. Untuk mengatasi itu, supervisor/guru senior memotivasi kepada guru tersebut supaya melaksanakan tindak lanjut.

4. Mengevaluasi hasil tindak lanjut hasil penilaian berjumlah 5 guru dengan persentase $50 \%$. Pelaksanaan ini belum dilakukan guru karena belum bisa membuat program. Hal ini berarti perlu memotivasi guru tersebut.

5. Menganalisis hasil evaluasi program tindak lanjut hasil penilaian berjumlah 54 guru dengan persentase $40 \%$. Hasil analisis yang dilakukan guru masih sedikit. Untuk meningkatkan gu MI Misbahussalam Sungai Punggu Lama agar mau menganalisis, kepala sekolah/guru senior selalu memotivasi guru tersebut. 


\section{e. Refleksi Tindakan Supervisor}

Hasil refleksi pada bagian pelaksanaan supervisi dan setelah diadakan diskusi dengan guru, peneliti, dan supervisor adalah sebagai berikut.

1. Supervisor memberikan indikator yang harus dicapai pada saat persiapan, pelaksanaan, dan penilaian seminggu sebelum pelaksanaan supervisi.

2. Superviso9r menyuruh guru mengisi format penilaian yang ingin dicapai, yaitu satu minggu sebelum pelaksanaan supervisi.

3. Supervisor mendiskusikan persiapan dengan guru yang akan disupervisi

4. Supervisor mengamati guru pada saat supervisi

5. Supervisor berdiskusi dengan guru settelah melaksanakan supervisi

6. Guru dan Supervisor membuat perencanaan kembali kegiatan berikutnya yang akan disupervisi.

Berdasarkan deskripsi dan refleksi di atas, peneliti, guru, dan supervisor melakukan tindak lanjut yang berkaitan dengan tindakan-tindakan yang perlu dilakukan pada siklus kedua, baik yang berkaitan dengan perencenaan, pelaksanaan, maupun penilaian. Guru yang disupervisi dan guru senior dibantu oleh supervisor membuat perencenaan pembelajaran yang kriterianya berdasarkan pada indikator yang telah dibuat oleh Ditjen Dikmenum.

Pada siklus 1 pelaksanaan supervisi difokuskan pada kerjasama dalam pembelajaran di kelas. Guru senior atau guru yang sudah mampu membantu pada guru junior atau guru yang belum mampu dalam pelaksanaan pembelajaran. Contoh-contoh pembelajaran perlu diperhatikan oleh guru yang belum mampu tersebut. Pada bagian penilaian ini guru berdiskusi dengan guru lain untuk menentukan penilaian yang cocok untuk pokokbahasan atau KD yang akan disampaikan pada siswa.

Pada penilaian bagian ini guru berdiskusi dengan guru lain untuk menentukan tindak lanjut penilaian karena banyak bagian yang belum dipahami oleh guru-guru MI Misbahussalam Sungai Punggu Lama, untuk itu, ada beberapa rekomendasi yang perlu ditndak lanjuti pada siklus II yaitu ; 1) para guru MI Misbahussalam Sungai Punggu Lama perlu workshop tentang tindak lanjut penilaian, untuk membicarakan; (a) identifikasi tindak lanjut hasil penilaian; (b) menyusun program tindak lanjut; (c) melaksanakan tindak lanjut; (d) mengevaluasi hasil tindak lanjut; (e) menganalisis hasil evaluasi program tindak lanjut hasil penilaian.

\section{B. Hasil Siklus II}

Siklus II dilaksanakan berdasarkan temuan siklus I. Bagian yang sudah baik baik dipertahankan. Bagian persentase yang keberhasilannya kecil perlu diperbaiki pada siklus II ini. Berdasarkan refleksi dan pelaksanaan tindak lanjut siklus I. gambaran hasil dan temuan yang perlu ditindak lanjuti adalah sebagai berikut.

\section{Perencanaan Supervisi Siklus II}

Guru berdiskusi dengan guru senior dan dibantu supervisor sekolah untuk merumuskan tujuan yang akan dicapai dalam pembelajaran. Tujuan itu bersumber pada KD/indicator atau pokok bahasan dan indicator kompetens guru yang telah dirumuskan Ditjen Dikmenum. Hasil pembuatan perangkat tersebut dipahami bersama sebelum diberikan pada siswa. Hasil pembuatan format penilaian pra-KBM sebagai berikut Tabel 5.

Tabel 5 Hasil Penentuan Perencanaan Siklus II

\begin{tabular}{|c|c|c|c|c|}
\hline No & Indikator & $\begin{array}{c}\text { Jumlah } \\
\text { Guru }\end{array}$ & $\begin{array}{c}\text { Jumlah Guru } \\
\text { Berhasil (Skor> 75) }\end{array}$ & $\begin{array}{c}\% \\
\text { Keberhasilan }\end{array}$ \\
\hline 1. & Mendeskripsikan tujuan pembelajaran & 10 & 10 & 100 \\
\hline 2. & $\begin{array}{l}\text { Menentukan materi sesuai dengan } \\
\text { kompetensi }\end{array}$ & 10 & 10 & 100 \\
\hline 3. & Mengorganisasikan materi berdasarkan & 10 & 8 & 80 \\
\hline
\end{tabular}




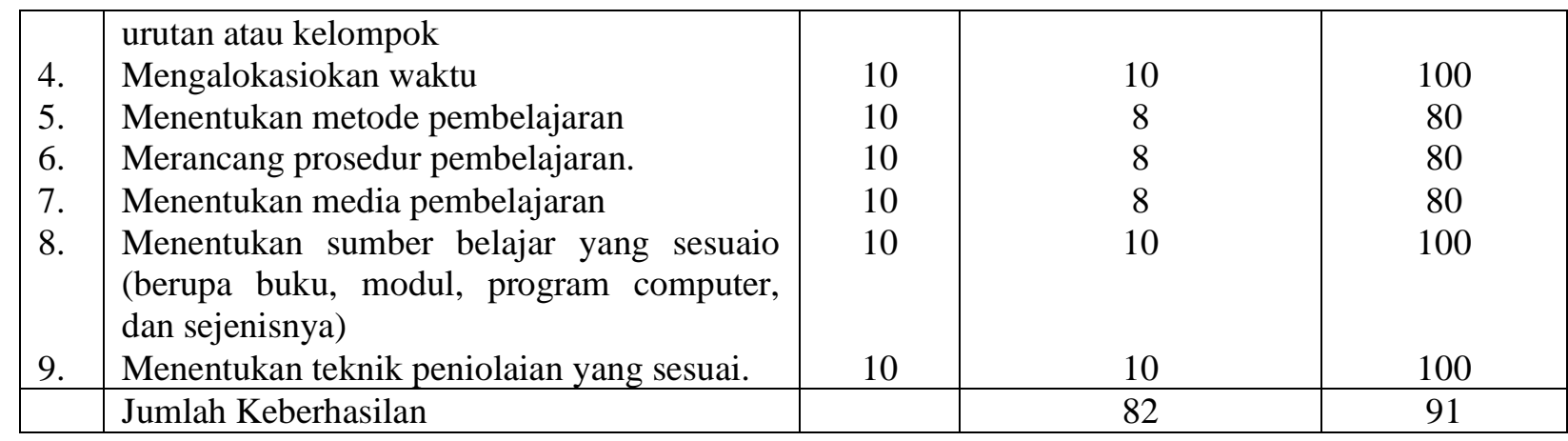

\section{Pelaksanaan Supervisi Siklus II}

Instrumen penelitian pada siklus II tetap menggunakan instrumen yang dibuat oleh pemerintah.menurut Ditjen $(2004 ; 10)$ dan hasilnya ditunjukkan pada Tabel 6.

Tabel 6 Hasil Pelaksanaan Pembelajaran Tindakan Siklus II

\begin{tabular}{|c|c|c|c|c|}
\hline No & Indikator & $\begin{array}{c}\text { Jumlah } \\
\text { Guru }\end{array}$ & $\begin{array}{c}\text { Jumlah } \\
\text { Guru } \\
\text { Berhasil } \\
\text { (Skor> 75) }\end{array}$ & $\begin{array}{c}\% \\
\text { Keberhasilan }\end{array}$ \\
\hline 1. & $\begin{array}{l}\text { Membuka pelajaran dengan metode yang } \\
\text { tepat }\end{array}$ & 10 & 9 & 90 \\
\hline 2. & $\begin{array}{l}\text { Menyajikan materi pelajaran secara } \\
\text { sistematis. }\end{array}$ & 10 & 8 & 80 \\
\hline 3. & $\begin{array}{l}\text { Menerapkan metode dan prosedur } \\
\text { pembelajaran yang telah ditentukan. }\end{array}$ & 10 & 8 & 80 \\
\hline 4. & Mengatur kegiatan siswa dikelas & 10 & 9 & 90 \\
\hline 5. & Menentukan media pembelajaran. & 10 & 8 & 80 \\
\hline 6. & Menggunakan sumber belajar & 10 & 10 & 100 \\
\hline 7. & $\begin{array}{l}\text { Memotivasi siswa dengan berbagai cara } \\
\text { yang positif. }\end{array}$ & 10 & 9 & 90 \\
\hline 8 & Melakukan interaksi dengan siswa & 10 & 9 & 90 \\
\hline 9. & menggunakan bahasa yang komunikatif. & 10 & 8 & 80 \\
\hline 10. & Menyimpulkan pembelajaran & 10 & 10 & 100 \\
\hline \multirow[t]{2}{*}{11.} & Menggunakan waktu secara efektif. & 10 & 10 & 100 \\
\hline & Jumlah Keberhasilan & 10 & 98 & 89 \\
\hline
\end{tabular}

\section{Penilaian Supervisi Siklus II}

Pada siklus II instrumen yang digunakan berdasarkan Ditjen $(2004 ; 11)$ dengan hasil sebagai berikut.

Tabel 7 Hasil Menilai Prestasi Belajar Siklus II

\begin{tabular}{|c|c|c|c|c|}
\hline No & Indikator & $\begin{array}{c}\text { Jumlah } \\
\text { Guru }\end{array}$ & $\begin{array}{c}\text { Jumlah Guru } \\
\text { Berhasil (Skor }>75)\end{array}$ & $\begin{array}{c}\% \\
\text { Keberhasilan } \\
\end{array}$ \\
\hline 1. & Menyusun soal/perangkat penilaian & 10 & 9 & 90 \\
\hline 2. & Melaksanakan penilaian & 10 & 10 & 100 \\
\hline 3. & Memeriksa jawaban/member skor & 10 & 8 & 80 \\
\hline 4. & Menilai hasil belajar & 100 & 10 & 10 \\
\hline 5. & Mengolah hasil belajar & 100 & 1 & 10 \\
\hline 6. & Menganalisis hasil belajar & 80 & 8 & 10 \\
\hline 7. & Menyimpulkan hasil belajar & 100 & 10 & 10 \\
\hline 8 & Menyusun laporan hasil belajar & 100 & 10 & 10 \\
\hline \multirow[t]{2}{*}{9.} & Memperbaiki soal/perangkat penilaian & 100 & 10 & 10 \\
\hline & Jumlah Keberhasilan & 96 & 85 & \\
\hline
\end{tabular}




\section{Tindak Lanjut Hasil Penilaian Siklus II}

Kegiatan ini dilaksanakan oleh guru pada bagian terakhir setelah melaksanakan penilaian dengan tujuan menganalisis program penilaian dan perbaikan hasil penilaian. Adapun instrumen yang digunakan Ditjen Dikmenum (2004; 12) dengan hasil sebagai berikut.

Tabel 8 Hasil Pelaksanaan Tindak Lanjut Hasil Penilaian Siklus II

\begin{tabular}{|l|l|c|c|c|}
\hline No & \multicolumn{1}{|c|}{ Indikator } & $\begin{array}{c}\text { Jumlah } \\
\text { Guru }\end{array}$ & $\begin{array}{c}\text { Jumlah Guru } \\
\text { Berhasil (Skor> 75) }\end{array}$ & $\begin{array}{c}\text { \% } \\
\text { Keberhasilan }\end{array}$ \\
\hline 1. & $\begin{array}{l}\text { Mengidentifikasi kebutuhan tindak lanjut } \\
\text { hasil penilaian }\end{array}$ & 10 & 8 & 80 \\
2. & $\begin{array}{l}\text { Menyusun program tindak lanjut } \\
\text { 3. }\end{array}$ Melaksanakan program tindak lanjut & 10 & 8 & 80 \\
4. & $\begin{array}{l}\text { Mengevaluasi hasil tindak lanjut hasil } \\
\text { penilaian }\end{array}$ & 10 & 8 & 80 \\
5. & $\begin{array}{l}\text { Menganalisis hasil evaluasi program tindak } \\
\text { lanjut hasil penilaian. }\end{array}$ & 10 & 9 & 90 \\
\hline & Jumlah Keberhasilan & & 42 & 84 \\
\hline
\end{tabular}

\section{Tindakan Supervisor Siklus II}

Tindakan supervisor pada pelaksanaan siklus pertama sebagai berikut. (1) supervisor memberikan indicator yang harus dicapai pada saat persiapan, pelaksanaan dan penilaian seminggu sebelum pelaksanaan supervisi. Guru yang disupervisi diajak diskusi tentang format tersebut, (2), supervisor menyuruh guru mengisi format penilaian yang ingin dicapai, satu minggu sebelum pelaksanaan supervisi. (3) supervisor mendiskusikan persiapan dengan guru yang akan disupervisi. (4) supervisor mengamati guru ada saat supervisi dengan cara berkolaborasi secara langsng dalam PBM. (5) supervisor berdiskusi dengan guru setelah melaksanakan supervisi. (6) guru dan supervisor menganalisis hasil belajar siswa dan membuat laporan bersama tentang pembelajaran. (7) guru dan supervisor menganalisis program yang telah dibuat untuk diperbaiki jika kurang sesuai.

\section{Refleksi Siklus II}

\section{a. Refleksi Perencanaan Supervisi Siklus II}

Setelah dilaksanakan diiskusi dengan guru mata elajaran dan supervisor, peneliti menulis hasil refleksi sebagai berikut.

1. Mendeskripsikan tujuan pembelajaran guru dengan persentase $100 \%$. Berdasarkan data tersebut, sudah mampu mendeskripsikan tujuan pembelajaran. Untuk itu, model seperti ini tetap dipertahankan.

2. Menentukan materi sesuai dengan kompetensi yang telah ditentukan guru dengan persentase $100 \%$. Ternyata guru sudah mampu menentukan materi pmbelajaran yang sesuai dengna kompetensinya. Guru lebih mudah menjalankan tugasnya jika supervisi edukatif dilakukan secara kolaboratif dengan supervisor.

3. Mengorganisasikan materi berdasarkan urutan dan kelompok dengan persentase $80 \%$.

4. Mengalokasikan waktu dengan persentase $100 \%$ kegiatan pada bagian ini dipertahankan, yakni menentukan alokasi waktu melalui workshop guru atau pelajaran disekolah dengan dipandu guru senior.

5. Menentukan metode pembeajaran yang sesuai sebanyak guru dengan persentase $80 \%$. Guru sudah banyak yang melaksanakan metode pembelajaran yang mengarah student center. Hal seperti ini perlu dipertahankan. 
6. Merancang prosedur pembelajaran sebanyak guru dengan persentase $80 \%$. Pada penentuan prosedur sangat berkaitan dengan metode pembelajaran. Oleh sebab itu, perlu ada perbaikan dibidang ini.

7. Menentukan media pembelajaran yang akan digunakan sebanyak guru dengan persentase $80 \%$. Ternyata pada bagian ini sudah banyyak guru yang menggunakan media yang ada $\mathrm{d}$ sekitar kelas. Hal ini bisa dilihat pada hasil diatas.

8. Menentukan sumber belajar yang sesuai (berupa buku modul, program computer, dan sejenisnya) sebanyak guru dengan persentase $100 \%$. Dalam menentukan sumber belajar, guru bervariatif.

9. Menentukan teknik penilaian sebanyak guru dengan persentase $100 \%$. Teknik-teknik yang dibuat guru dalam menyusun penilaian sudah beragam. Ada yang menggunakan portofolio, kinerja, proyek, kuis, dan psikomotorik.

\section{b. Refleksi Pelaksanaan Supervisi Siklus II}

Hasil refeksi bagian pelaksanaan supervisi dan setelah diadakan disuse dengaan guru, peneliti, dan supervisor sebagai berikut.

1. Membuka pelajaran dengan metode yang sesuai.guru rata-rata sudah mampu membuka pelajaran dengan meode yang tepat.

2. Menyajikan materi pelajaran. Dalam menyajikan materi pelajaran, guru rata-rata sudah baik dan berdasarkan pengamatan guru yang dikategorikan baik.

3. Menerapkan metode dan prosedur pmbelajaran yang telah ditentukan dengan persentase $80 \%$. Guru dalam menggunakan metode pembelajaran sudah mengarah ke model CTL.

4. Mengatur kegiatan siswa di kelas dengan persentase $94 \%$. Berdasarkan data tersebut guru sudah banyak yang mampu mengelola kelas.

5. Menggunakan media pembelajaran/peralatan praktikum (dan bahan) yang telah ditentukan dengan persentase $80 \%$.

6. Menggunakan sumber belajar yang telah dipilih berua buku modul, program computer, dan sejenisnya dengan pesentase $10 \%$. Pada bagian ini guru sudah tidak ada masalah lagi.

7. Memotivasi siswa dengan berbagai cara yang psitif dengan persentase $90 \%$. Guru sudah banyak yang akan memotivasi siswa. Kegiatan seperti ini perlu dipertahankan.

8. Melakukan interaksi dengan siswa menggunakan bahasa yang komunikatif dengan persentase $90 \%$

9. Memberikan pertanyaan dan umpan baik untuk mengetahui dan memperkuat penerimaan siswa dalam proses dengan persentase $80 \%$.

10. Menyimpulkan pembelajaran dengan persentase $100 \%$.

11. Menggunakan waktu secara efektif dan efisien dengan persentase $100 \%$. Pada siklus II guru dapat memanfaatkan waktu secara efektif dan efisien. Cara seperti ini perlu dipertahanan.

\section{c. Refleksi Penilaian Supervisi Siklus II}

Hasil refleksi pada bagian penilaian supervisi dan sekolah diadakan diskusi dengan guru, peneliti, dan supervisor adalah sebagai berikut.

1. Menyusun soal/perangkat penilaian sesuai dengan indicator/criteria unjuk kerja yang telah ditentukan berjumlah 10 guru dengan persentase $90 \%$. Masih ada satu guru yang belum mampu menyusun soal penilaian karena masih tidak sesuai dengan indikatornya. Berdasarkan pengamatan/analisis ternyata guru tersebut pada pertemuan dengan supervisor tidak masuk karena sakit. Dengan demkian guru yang belum berhasil perlu belajar sendiri dengan guru yang sudah mampu.

2. Melaksanakan penilaian berjumlah 10 guru dengan persentase $100 \%$. Hampir semua guru sudah melaksanakan penilaian sesuai dengan aturan. Siswa tidak boleh membuka dan bertnya kepada siswa lain. Hal seperti ini perlu dilakukan karena penilaian itu untuk mengukur anak yang sudah mampu atau yang belum mampu. 
3. Memeriksa jawaban/memberikan skor tes hasil belajar berdasarkan indkator/criteria unjuk kerja yang telah ditentukan berjumlah 8 guru dengan persentase $80 \%$. Guru sudah mampu memberikan skor soal.cara seperti yang sudah dilakukan perlu dipertahankan.

4. Mengolah hasil penilaian berjumah 31 guru dengan persentase $100 \%$. Guru sudah mampu mengolah nilai, mulai dari penskoran, pembobotan, sampai pada pemberian nilai siswa.

5. Menganalisis hasil penilaian (berdasarkan tingkat kesukaran, daya pembeda, validitas, dan reabilitas) berjumlah 25 guru dengan persentase $81 \%$. Guru yang ttidak bisa menganalisis soal berjumlah 6 orang dan rata-rata guru yang enggan menganalisis atau tidak mau menganalisis sehingga lupa cara menganalisis. Untuk menghadapi seperti itu, sekolah perlu mengadakan diskusi dengan guru yang belum mampu tersebut dengan mendatangkan narasumber.

6. Menyimplkan hasil penilaian secara jelas dan logis (misalnya; interpretasi kecenderungan hasil penilaian tingkat pencapaian siswa, dll)berjumlah 30 guru dengan persentase $97 \%$.

7. Menyusun laporan hasil penilaian berjumlah 30 guru dengan persentase $97 \%$. Pada bagian ini perlu dipertahankan karena $97 \%$ berhasil dalam pembelajaran

8. Memperbaiki soal/perangkat penilaian berjumlah 31 guru dengan persentasi $100 \%$. Semua guru pada siklus II ini sudah bisa memperbaik soal yang kurang valid. Dengan demikian guru tetapmempertahankan cara memperbaiki soal terebut

\section{d. Refleksi Pelaksanaan Tindak Lanjut Penilaian Siklus II}

Refleksi pada bagian tindak lanjut ini dilakukan berdasarkan pada data yang dikumpulkan oleh supervisor dan dianalisis lalu dicarikan solusinya. Hasil refleksinya adalah sebagai berikut.

1. Mengidentifikasi kebutuhan tindak lanjut hasil penilaian berjumlah 25 guru, dengan persentase $85 \%$. Pada siklus II perkembangan guru pesat sekali karena tinggal enam guru saja yang belum mencapai skor 75 . Untuk itu,guru perlu mempertahankan model mengidentifikasi kebutuhan tindak lanjut.

2. Menyusun program tindak lanjut hasil penilaian berjumlah 8 guru, dengan persentase $80 \%$. Dengan adanya supervisi edukatif berkolaboratif ternyata banyak guru yang sebelumnya tidak bisa menyusun program tindak lanjut. Ternyata pada siklus II berhasil menyusun dengan skor lebih dari 75. Berarti, model ini perlu dipertahankan oleh sekolah.

3. Melaksanakan tindak lanjut berjumlah 8 guru dengan persentase $80 \%$. Guru MI Misbahussalam Sungai Punggu Lama sudah banyak melaksanakan tindak lanjut penilaian. Ini terbukti 8 guru telah melaksanakan dengan baik sedangkan enam guru sudah melaksanakan tindak lanjut tetapi skor yang dicapai masih dibawah 75 .

4. Mengevaluasi hasil tindak lanjut hasil penilaian berjumlah 9 guru dengan persentase 90\%. Karena sklus II ini guru sudah mampu mengevaluasi hasil tindak lanjut, tindakan guru tersebut perlu dipertahankan.

5. Menganalisis hasil evaluasi program tindak lanjut penilaian walaupun masih ada duaguru yang hasil analisisnya kurang memadai.

e. Refleksi Tindakan Supervisor Siklus II

Hasil refleksi pada bagian pelaksanaan supervisi dan setelah diadakan diskusi dengan guru, penelti, dan supervisor sebagai berikut.

1. Supervisor memberikan indicator yang harus dicapai pada saat persipaan pelaksanaan dan penilaian seminggu sebelum pelaksanaan supervisi. Guru yang sudah diberi format penilaian perlu diisi dan dipahami.

2. Supervisor menyuruh guru mengisi formatpenilaian yang ingin dicapai, satu minggu sebelum pelaksanaan supervisi.

3. Supervisor mendiskusikan persiapan dengan guru yang akan disupervisi.

4. Supervisor mengamati guru pada saat supervisi.

5. Supervisor berdiskusi dengan guru setelah melaksanakan supervisi. 
6. Guru dan supervisor membuat tindak lanjut program penilaian.

Berdasarkan deskripsi dan refleksi diatas, peneliti, guru, dan suipervisor menghentikan penelitian tindakan ini karena hasil yang diperoleh setelah tindakan baik yang dilakukan oleh guru, supervisor, maupun guru senior sudah memuaskan.

\section{Pembahasan}

Berdasarkan hasil penelitian di atas, peneliti membhasnya dari segi pengalaman peneliti pada saat menjadi supervisor pada guru inti mata pelajaran karena diberi tugas mensupervisi guru tersebut. Selain itu, pembahasan didasarkan pada teori-teori yang sudah ada, baik berdasarkan pada referensi maupun dari ucapan ahli di bidang penelitian ini. Adapun pembahasan hasil penelitian aini adalah sebagai berikut.

Temuan pertama,kinerja guru meningkat ketika membuat perencanaan pembelajaran. Hal ini terjadi karena aanya kerja sama antara guru mata pelajaran yang satu dengan lainnya dibantu oleh guru senior yang ditugasi oleh kepala sekolah untuk mensupervisi guru tersebut.langkah-langkah yang dapat meningkatkan kinerja guru dalam membuat persiapan pembelajaran adalah sebagai berikut. (1) guru senior/supervisor memberikan format supervisi dan jadwal supervisi pada awal tahun pelajaran atau awal semester. Pelaksanaan supervisi tidak hanya diakukan sekali. (2) guru senior selalu menyakan perkembangan pembuatan perangkat pembelajaran (mengingatkan betapa pentingnya perangkat pembelajaran). (3) satu minggu sebelum pelaksanaan supervisi perangkat pembelajaran, supervisor/guru senior menanyakan format penilaian. Jika format yang diberikan pada awa tahun pelajaran tersebut hilang, guru yang bersangkutan disuruh memotokopi arsip sekolah. Jika diseklah masih banyak format seperti itu, guru tersebut diberi kembali. Bersamaan dengan member/menanyakan format, supervisor meminta pengumpulan perangkat pembelajaran yang sudah dbuatnya untuk diteliti kelebihan dan kekuranganya. (4) supervisor memberikan catatan-catatan khusus pada lembaran untuk diberikan kepada guru yang akan disupervisi tersebut.(5) supervisor dalam menilai perangkat pembelajaran penuh perhatian dan tidak mencerminkan sebagai penilai. Supervisor bertindak sebagai kolaborasi. Supervisor membimbing dan mengarahkan guru yang belum bisa tetapi supervisor juga menirima argument guru yang positf. Dengan adanya itu terciptalah hubungan yang akrab antara guru dan supervisor. Tentu saja ini akan membawa nilai positif dalam pelaksanaan pembelajaran.

Temuan kedua, kinerja guru meningkat dalam melaksanakan pembelajaran. Dalam penelitian tindakan ini ternyata dari tiga puluh satu guru hampir semuanya mampu melaksanakan pembelajaran dengan baik. Hal ini terbukti dari hasil supervisi. Langkahlangkah yang dilakukan untuk meningkatkan pelaksanaan pembelajaran berdasarkan penelitian tindakan ini adalah sebagai berikut. (1) supervisor yang mengamati guru mengajar tidak sebagai penilai tetapi sebagai rekan bekerja yang siap membantu guru tersebut. (2) selama pelaksanaan supervisi dikelas, guru tidak menganggap supervisor sebagai penilai karena sebelum pelaksanaan supervisi guru dan supervisor telah berdiskusi permasalahanpermasalahan yang ada dalam pembelajaran tersebut. (3) supervisor mencatat semua peristiwa yang terjadi di dalam pembelajaran, baik yang positif maupun yang negative. (4) supervisor selalu member contoh pembelajaran yang berorientasi pada modern learning.(5) jika ada guru yang pembelajarannya kurang jelas tujuan, penyajian, dan umpann baliknya,supervisor memberikan contoh bagaimana menjelaskan tujuan menyajikan, member umpan balik kepada guru tersebut. (6) setelah guru diberi contoh pembelajaran modern, supervisor setiap dua atau tiga minggu mengunjungi atau mengikuti guru tersebut dalam proses pembelajaran.

Temuan ketiga, kinerja guru meningkat dalam menilai prestasi belajar siswa. Pada penelitian tindakan yang dilakukan di MI Misbahussalam Sungai Punggu Lama ini ternyata pelaksanaan supervisi edukatif kolaboratif secara periodik memberikan dampak positif terhadap guru dalam menyusun soal/perangkat penilaian, melaksanakan, memeriksa, menilai, mengolah, menganalisis, menyimpulkan, menyusun laporan,dan memperbaiki soal. Sebelum 
diadakan supervisi edukatif secara kolaboratif, guru banyak yang mengalami kesulitan dalam melaksanakan penilaian. Langkah-langkah yang dilakukan dalam supervisi edukatif kolaboratif secara periodik yang dappat meningkatkan kinerja guru adalah sebagai berikut. (1) supervisor berdiskusi dengan guru dalam pembuatan perangkat penilaian sebelum dilaksanakan supervisi. (2) guru melaksanakan penilaian sesuai dengan aturan yang telah ditetapkan bersama supervisor, sebagai kolaboratif dalam pembelajaran. (3) guru membuat criteria penilaian yang berkaitan dengan penskoran, pembobotan, dan pengolahan nilai, yang sebelum pelaksanaan upervisi didiskusikan dengan supervisor. (4) gur menganalisis hasil penilaian dan melaporkannya kepada urusan kurikulum.

Temuan keempat, kinerja guru meningkat dalam melaksanakan tindak lanjut hasil penilaian prestasi belajar peserta didik. Langkah-langkah yang dapat meningkatkan kinerja guru dalam supervisi edukatif kolaboratif yaitu sebagai berikut.(1) supervisor dan guru bersama-sama membuat program tindak lanjut hasil penilaian. (2) guru senior/supervisor member contoh pelaksanaan tindak lanjut, yang akhirnya dilanjutkan oleh guru dalam pelaksanaan yang sebenarnya. (3) supervisor atau guru senior mengajak diskusi pada guru yag telah membuat, melaksanakan, dan menganalisis program tindak lanjut.

Temuan kelima, kinrja guru meningkat dalam menyusun program pembelajaran, melaksanakan pembelajaran, menilai prestsi belajar, dan melaksanakan tindak lanjut hasil prestasi belajar siswa ternyata membawa kenaiakan prestasi siwa dalam mengikuti Ujian Akhir Sekolah.

\section{PENUTUP}

Berdasarkan temuan hasil penelitian, dapat disimpulkan bahwa dengan adanya supervisi teman sejawat dan edukatif kolaboratif dapat meningkatkan kinerja guru dalam menyusun rencana pembelajaran, melaksanakan pembelajaran, menilai prestasi belajar dan tindak lanjut hasil penilaian prestasi belajar siswa.

\section{DAFTAR PUSTAKA}

Aqib, Zainal. 2006. Penelitian Tindakan Kelas. Bandung; Yrama Widya -2003. Undang-Undang Republik Indonesia Nomor 20 Tahun 2003 Tentang Sistem Pendidikan Nasional. Jakarta

2004. Standar Kompetensi Guru Sekolah Dasar. Jakarta; Depdiknas.

2004. Kurikulum 2004 Pedoman Pemilihan Bahan dan Pemanfaatan Bahan Ajar. Jakarta; Depdiknas.

2004. Kurikulum 2004. Pedoman Supervisi Pengajaran Sekolah Dasar. Jakarta: Depdiknas

2004. Petunjuk Pelaksanaan Supervisi Penddikan di Sekolah Dasar. Jakarta : Depdiknas

---------. 2003. Penuntasan Wajib Belajar Pendidikan Dasar Sembilan Tahun. Jakarta: Depdiknas.

---------. 2001. Manajemen Berbasis Sekolah. Jakarta: Depdiknas

Mulyasa, E. 2003. Manajemen Berbasis Sekolah,Konsep, Strategi dan Implementasi. Bandung: Rosda Karya.

Perwanto, Ngalim. 1987. Administrasi dan Supervisi Pendidikan. Bandung: Remaja Karya.

Pidarta, I Made. 1990. Perencana Pendidikan Dengan Pendekatan Sistem. Jakarta; Rineka Cipta. 